\title{
The road to solvency: How the Icelandic pension funds achieved actuarial balance in the 1990s
}

\author{
Ólafur Ísleifsson ${ }^{1}$
}

\begin{abstract}
Ágrip
Í greininni er leitað að skýringum pess að lífeyrissjóðir hins almenna vinnumarkaðar snerust um eða upp úr miðjum tíunda áratug liðinnar aldar úr að vera ógjaldfærir í að eiga fyrir skuldbindingum sínum á tryggingafræðilegan mælikvarða. Greiningin er að verulegu leyti reist á óbirtum tryggingafræðilegum úttektum og eru fjórir valdir lífeyrissjóðir sérstaklega teknir fyrir. Greiningin leiðir í ljós að pættir eins og verðtrygging fjárskuldbindinga, góð ávöxtun eigna, breyting á reikniforsendu um ávöxtun eigna lífeyrissjóða og skerðing á réttindum sjóðfélaga hafi hver um sig haft vægi. Leidd eru rök að pví að verðtrygging eigna sjóðanna, sem fól í sér að verðlagsáhættu var að umtalsverðu leyti létt af sjóðunum, hafi mestu skipt í pessu efni.
\end{abstract}

\begin{abstract}
This paper presents the results of a study on how the Icelandic private market pension funds achieved actuarial balance after sustaining a relatively long period of being less than solvent. The study, being largely based on unpublished data, focuses on the pension funds' actuarial balances given that their investment performance is confined to a limited selection of asset classes available to them in the first decades of their operations. It is shown that apart from the introduction of price indexation of important classes of fixed income instruments, several measures undertaken by the funds contributed to make them able to meet their obligations.
\end{abstract}

JEL flokkun: H55, J3

Lykilorð: Actuarial pension deficit, pension rights, pension asset classes, discount rate, price indexation

${ }^{1}$ Dr. Ólafur Ísleifsson is Associate Professor of Economics at Bifröst University. This paper is in part based on research presented in Chapter 2 of the author's PhD dissertation defended in May 2013 at the Economics Department of the University of Iceland (Ólafur Ísleifsson, 2013a). I thank Sigurður Guðjón Gíslason for research assistance, and Helgi Tómasson, Ólafur Birgir Davíðsson and Kristján Kristjánsson for providing helpful advice. Ragna Björk Kristjánsdóttir provided useful advice on the final draft of the paper. I also thank two referees for useful comments. Any remaining errors are mine. 


\section{Introduction}

In the notes to the bill that became the 1997 Pension Act ${ }^{2}$, it was claimed that, up until the 1990s, the future of the pension fund system had been subject to much uncertainty. In the notes it is stated: "Only fifteen years ago, most signs indicated that the pension fund system would not reach its goals; the whole system would eventually collapse." At that time, however, the financial position of most funds operating without employer guarantees had changed dramatically over the previous years and had become adequate in the actuarial sense. Instead of suffering negative returns, as they had over the first few years of operations, they had now achieved returns on their assets that far exceeded what was required from an actuarial perspective. In addition, several funds had merged and their obligations aligned more carefully with their current asset positions (Pingskjal 294, 1997-1998).

The majority of the pension funds of the general labour market were established on the basis of collective wage agreements signed in the spring of 1969. ${ }^{3}$ In their early years, pension funds suffered from weak financial performance, mainly due to poor investment returns which were the result of the eroding value of non-indexed bonds whose real values decreased significantly due to inflation. As will be discussed in more detail below, the funds were far from being able to meet their obligations as stipulated in their bylaws.

In the mid-1970s, Central Bank of Iceland Governor Jóhannes Nordal stated it was well known that pension funds in Iceland had usually been far from achieving positive returns over the preceding two to three decades. In some years returns had been negative by sizeable amounts as inflation had far exceeded interest rates and therefore the available returns on various types of securities. He further observed that the funds had been organized so that they would need to achieve real annual returns on assets of at least $4 \%$ to be able to meet their obligations. Up until then, most loans made by pension funds had been mortgages at the highest permissible interest rate (Jóhannes Nordal, 1975).

Just over a decade later in 1988 Hallgrímur Snorrason warned that the pension system was headed for trouble due to low returns associated with high inflation in the previous decades which peaked in 1973-1983 (Hallgrímur Snorrason, 1988). For most of this period, funds were not permitted to index their loans to members. However, the interest rate on loans was generally limited to a maximum, which nonetheless proved so low that real interest rates were usually negative and sometimes very much so.

The turnaround in the funds' finances was radical and contributed to the pension fund system going from being close to falling apart financially to being strong enough to becoming generally solvent in actuarial terms.

The research questions posed for this paper are the following:

1. Did the position of the funds improve over the period under study?

2. Which factors contributed to an improved position of the funds?

2 Act no 129/1997 on Mandatory Pension Insurance and the Operation of Pension Funds.

${ }^{3}$ On pensions in the private labour market, see Ólafur Ísleifsson (2007). 


\section{The evolution of four selected pension funds}

This section provides a detailed overview of four pension funds. These four particular funds were selected as they all operated continuously over the time period that the present study considers. Three of the funds are; the Pension Fund of Commerce, the largest private labour market pension fund, founded in 1956, the Physicians' Pension Fund (now part of the Almenni pension fund), founded in 1967, and the Engineers' Pension Fund, founded in 1954. These are all examples of occupational pension funds. The last of the four is the Westman Islands Pension Fund, founded in 1970, which is an example of a pension fund serving a specific geographical region. ${ }^{4}$ The Physicians' and Engineers' funds have in common that their boards are solely composed of fund members, without employer involvement.

The study is based on actuarial assessments of the pension funds. A thorough description of the methods applied and international practice in this field is given in Ólafur Ísleifsson, 2009.

\subsection{The Pension Fund of Commerce}

Actuarial evaluations for the Pension Fund of Commerce are available for the end of 1970 and 1975. The year-end evaluation for 1970 showed that, in order for the fund to be able to meet its obligations, annual investment returns had to exceed wage increases by $3 \%$ on average (Pórir Bergsson, 1972). The impact of investments returns indicated that if the fund were to achieve average annual returns in excess of $4 \%$, members' benefits could be increased.

The fund's rules remained virtually unchanged from its inception in 1956 up until 1975. All benefits were non-indexed except for child benefits. A report on the fund's financial performance as of the end of 1975 was based on the idea that it would pay benefits out of current contributions and that its future actuarial position would be mostly determined by the ratio of contributions to benefits (Pétur H. Blöndal, 1976). The report's author expressed the view that the fund would run into insolvency within a half century if benefits were to be indexed. The fund's actuarial position was evaluated on the basis of the accumulation of contributions, by assuming a $10 \%$ contribution rate and increasing wages and capital returns based on the fund's evolution and experience over the previous decade. The results indicated that additional funding of ISK 12 billion $^{6}$ was needed so that the fund could meet its nonindexed obligations. ${ }^{7}$ Furthermore, the author pointed out that a negative real return of $9 \%$, as had been experienced over the previous decade, could hardly be sustained in the long run.

Significant changes were made via new bylaws in $1979 .{ }^{8}$ The major amendments to the previous bylaws were the following:

- A points system was established for determining benefits that were to increase proportionally with wages according to the Verslunarmannafélag Reykjavíkur (VR) union's wages. Baseline salaries were established with the purpose of inflationindexing contributions from previous years (and to make older contributions

${ }^{4}$ Data for the West Fjords Pension Fund, which would have been another example of a regional fund, were not available.

${ }^{5}$ Jakob F. Ásgeirsson (1986) provides an outline of the fund's history.

${ }^{6}$ The necessary ISK adjustments have been made.

${ }^{7}$ The fund's liabilities are not specified; it is thus not possible to represent the result as a proportion.

${ }^{8}$ The regulation is published in the fund's 1979 Annual Report (Pension Fund of Commerce, 1980). 
comparable with more recent ones) and to index contributions in the future, thereby assuring pensioners that pension benefits would increase in proportion to wages. Thus the VR union's wage rate remained the reference wage until August 31, 1985.

- An individual's rights to pension benefits were typically established after a total of ten years of contributions but this period was shortened significantly, down to approximately two to three years, or the equivalent of 3 points.

- Provisions on maximum contributions were extended.

- A decision was made to carry out actuarial evaluations every five years. The fund's assets would always have to be sufficient to cover at least fifteen years of future benefit provisions. If the fund's assets did not meet this requirement, attempts would be made to increase the fund's investment performance, but if that approach failed, contributions were to be increased. Finally, if these two methods proved unsuccessful, benefits would be reduced. ${ }^{9}$

- The fund's child benefits were lowered compared to previous bylaws to levels that were $50 \%$ higher than child benefits offered by public social security.

An actuarial appraisal of the fund was carried out for the end of 1982 (Bjarni Pórðarson, 1983). The appraisal was based on the usual assumption that the fund was closed to new members, and that current members of the fund in 1982 would continue to provide benefits according to their obligations. The assessment was based on a real discount rate of $2 \%$ in excess of increases in the wage index and showed a deficit of $23.5 \%$ as a proportion of total liabilities. All discount rates referred to in this paper are real rates.

The next actuarial appraisal of the Pension Fund of Commerce was made for year-end 1987 (Pétur H. Blöndal, 1988). In his report the actuary concluded that the fund was running a total deficit of $24.7 \%$, assuming a $2 \%$ discount rate and a $5.7 \%$ deficit assuming a $3 \%$ rate.

The next actuarial evaluation of the fund's financial position was carried out at year-end 1991. Assuming a real discount rate of $3 \%$ beyond wage changes, the evaluation showed that the fund was running a surplus of $9.4 \%$. This represents a turnaround in the fund's finances. The fund's 1991 annual report, referring to this actuarial assessment, states that the fund had achieved a balanced position between its assets and liabilities (Pension Fund of Commerce, 1991, p. 16). It further states that the fund's position had improved significantly over the preceding years, primarily due to stellar investment returns.

The subsequent evaluation of the fund's position was carried out at year-end 1992. Assuming a $3 \%$ real discount rate over the next decades, the results indicated a surplus of $6.7 \%$. The fund's 1992 annual report, referring to this evaluation, states that the fund had reached permanent stability by achieving a long-term balance between assets and liabilities (Pension Fund of Commerce, 1992, p. 13).

An actuarial appraisal for year-end 1995 yet again confirmed this enduring progress. From that time onwards, a real discount rate of $3.5 \%$ was applied. The results of the appraisal indicated that the fund's total assets exceeded liabilities by ISK 958 million or, equivalently, that the fund was running a positive surplus of $2.5 \%$.

In 1993, new provisions of the prevailing bylaws were established, stipulating that pensions would evolve according to the credit terms index, which consisted of the CPI, the

${ }^{9}$ For a discussion of the solvency rules introduced for pension funds by the Pension Act no. 129/1997 see Ólafur Ísleifsson (2009, pp. 134-136), and Ólafur Ísleifsson (2013a, Chapter 1, Sections 7.1 and 7.2). 
wage index and the building costs index in equal weights (Pension Fund of Commerce, 1992, p. 13). At the same time, spousal benefits were slightly augmented. Through this change, both the fund's assets and liabilities now rested on the same indexation base. The credit terms index was abandoned as the reference index in 1995 and was replaced by the consumer price index. From January 1996, the fund's benefits were altered according to changes in the consumer price index. From 1 September 1985 to year-end 1992 the fund's board of directors had made decisions regarding changes in benefits, in particular, no longer referring to the VR union's wages, as had been done since 1979 (Porgeir Eyjólfsson, personal communication, May 4, 2009). In 2005, the fund's rules were substantially modified by adopting an age-dependent pension rights accumulation (Pension Fund of Commerce, 2006, pp. 8-9). Since 1997, actuarial assessments have been performed annually. Those results, along with the older ones discussed above, are summarized in Figure 1.

From the fund's inception until 1970, the bulk of the fund's loan portfolio was comprised of loans to current fund members, but once mandatory membership was established, the fund increased loans to its affiliated private enterprises. In accordance with Act no. 82/1978, which obliged pension funds to purchase inflation indexed bonds from various credit providers and investment funds, all loans made to companies and other credit providers were fully indexed from mid-1978 on (Pension Fund of Commerce, 1979, p. 10).
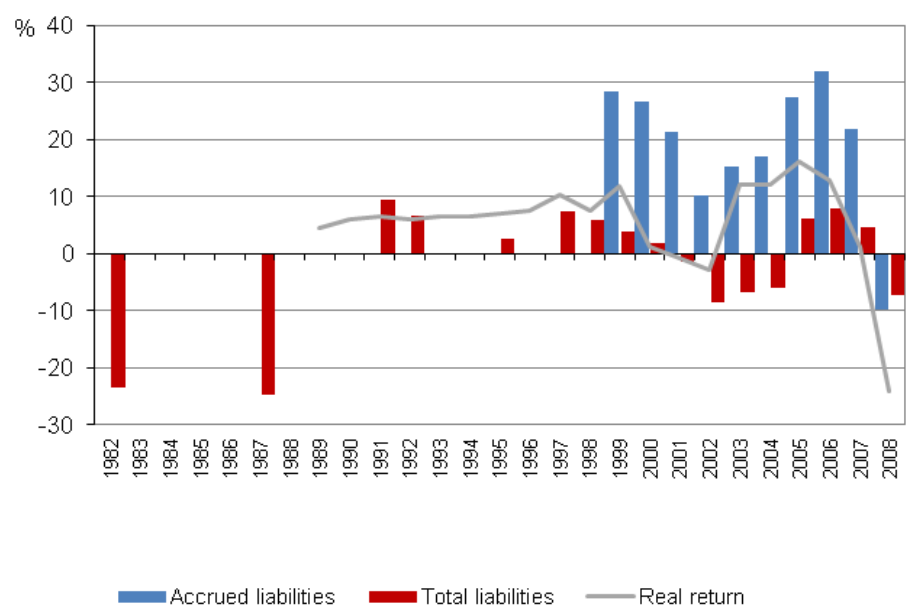
fund.

Source: Actuarial appraisals, annual reports of the Pension Fund of Commerce and data on real returns provided by the

Remarks. Results assume a 3.5\% real discount except for 1982 which assumes a 2\% return in excess of changes in the wage index; 1987, assuming a 3\% rate in excess of the wage index; and 1991-92, assuming a real discount rate of $3 \%$.

Figure 1. Pension Fund of Commerce: Actuarial assessments 1982-2008. Deficit or surplus as a proportion of accrued and total liabilities

From the fund's inception, all loans to members were non-indexed, issued at the highest permissible interest rate less one percentage point. In the 1970s and 1980s, such terms were far from sufficient to cover both rapid price and wage increases and this significantly deteriorated the fund's assets. In April 1982, the fund sought permission from the Central Bank of Iceland to index its loans to the building costs index at a fixed interest rate of $2 \%$ (Porgeir Eyjólfsson, personal communication, May 4, 2009). Lending activities under such terms took off in early 1979. In that year, indexation of financial obligations became generally permissible (Lög um stjórn efnahagsmála o.fl. nr. 13/1979). On 1 June 1980, the fund's board decided that only 
applications for indexed loans from current members would be considered (Pension Fund of Commerce, 1981, p. 21). All new loans issued by the fund were thus inflation-indexed from that time on.

In the fund's early years, investments in equities were minimal. Such investments were made on the basis of the stipulation in the fund's rules, which required that it could allocate up to $10 \%$ of its capital to equity investments (Pension Fund of Commerce, 1981, p. 21). In 1986-96 equities consistently were less than 5\% of the fund's total assets. However, it is important to bear in mind that transactions in an organized stock exchange in Iceland only began in the late 1990s. The low proportion of stock holdings over this period indicates that rising equity prices played at most a minor role in the fund's financial turnaround.

The fund's 1993 annual report states that the rules had been amended to allow for potential investments in foreign equities (Pension Fund of Commerce, 1994, p. 13).

In early 1994, the rules were further amended to allow for purchases of domestic corporate bonds of financially strong corporations, as such bonds were, in addition to the corresponding corporate stocks, listed on the Icelandic stock exchange (Pension Fund of Commerce, 1995, p. 13). These additional permissions to purchase foreign stocks and domestic corporate bonds were established after the fund had reached a balanced position and thus do not play a role in the fund's financial turnaround.

\subsection{The Westman Islands Pension Fund ${ }^{10}$}

The first recorded actuarial evaluation of the Westman Islands Pension Fund is based on the fund's position at year-end 1989 (Guðjón Hansen, 1990). From the fund's inception up until 1981, it suffered poor investment returns with wide fluctuations between good and bad years. The fund's deficit at the end of the year was approximately one-third of total liabilities. With respect to accrued liabilities, the deficit was roughly $27 \%$. Despite a deficit of this magnitude, the fund's actuary claimed that, excluding special benefits for fishermen, the fund's position was likely better than that of similar funds within the Icelandic Pension Funds Association (IPFA) (Guðjón Hansen, 1990, p. 6). The deficit was rooted in the same factors as other pension funds, in particular large-scale asset erosion due to excessively high rates of inflation over the course of at least a decade, as well as expenditures on the basis of the 1970 Act on pension benefits for elderly members of labour unions. ${ }^{11}$ The only adverse factor that was unique to the Westman Islands Pension Fund appears to have been the special pension rights for fishermen. ${ }^{12}$

From early 1992, the fund's base salaries were indexed to the credit terms index. Given that over the long run wages usually increase in excess of the price level as is reflected in higher costs of living, a 3.5\% discount rate was adopted instead of a 3.0\% rate applied when pension benefits were linked to wage developments (Guðjón Hansen, 1993, p. 3).

10 The fund adopted this name in 1997.

${ }^{11}$ On payments by pension funds for the purpose of partially financing a special pension scheme established by the Government of Iceland for elderly workers that foreseeably would not enjoy any significant pension benefits see (Ólafur Ísleifsson, 2013b).

${ }_{12}$ In addition to old-age pensions, disability benefits and more, the fund's rules contained provisions on special benefits for fishermen. Fund members who had been fishermen for 25 years or more, and who had spent an average of 180 days per annum at sea, could start drawing their pensions at age 60. Members who had worked as fishermen for 20-25 years could start to draw pensions at 61, and those who had worked as fishermen for 10-15 years could receive old-age benefits at 62 . 
By year-end 1992 the fund's deficit in relation to accrued liabilities had virtually disappeared and was approximately $4 \%$. The deficit in relation to total liabilities had also shrunk significantly. A large portion of the fund's investment portfolio was comprised of bonds bearing high interest rates; this was also the case for most other similar pension funds. Furthermore, the deficit would have appeared smaller if the bond portfolio's book value had been adjusted upward to reflect significantly higher market values of such bonds at the time. The fund's financial turnaround was traced to good investment returns over the five previous years, changes in contribution schedules in 1987-1990, when it became mandatory for members to pay a proportion of their total earnings instead of only baseline wages, and finally, the fact the baseline wages had been indexed to the credit terms index. The fund's actuary concluded that the fund was close to reaching financial stability were it not for special fishermen benefits (Guðjón Hansen, 1993, p. 5). Similar opinions regarding the fund's financial position were voiced at the end of 1994. At that time, the fund was believed to have the financial capacity to meet all accrued liabilities. Most other funds within IPFA had reached this kind of stability at that time. Moreover, the Westman Islands Pension Fund had enjoyed a favourable member age composition, along with low ratios of benefit payments to contributions during a period of stellar investment returns. However, the fund's position was perhaps slightly more challenging than that of other funds due to special benefit provisions regarding fishermen and spousal pensions. Other funds within IPFA generally did not carry any such special obligations (Guðjón Hansen, 1995, p. 9).

Provisions in the fund's bylaws on spousal pensions were amended in 1993 when new proposals were put forth by IPFA and agreed upon with substantial modifications. The impact of this new proposal on the Westman Islands Pension Fund was estimated for the end of 1993. Had the proposal been passed without modifications, the fund would have seen a total deficit in the order of approximately $22 \%$; however, with modifications, the introduction of the proposal was expected to lead to a deficit of around $25 \%$ of total liabilities. Finally, accounting for all modifications to the new proposals on spousal pensions, the total effect on the fund's finances was expected to lead to a total deficit of around $24 \%$. The fund's total cost due to changes in spousal pension rights, in excess of what IPFA bylaws strictly stipulated, thus amounted to around $2 \%$ of the fund's total liabilities.

The vast difference shown in these years between the accrued position of the fund, due to its operations in the past, and its total position, which accounts for its future operations, lies in the fact that rights in the past have been accumulated by relatively young members in a system of accruals, independent of age. This implies that their contributions have been invested over a longer period of time once benefit payments commence. Future contributions, on the other hand, will be invested over shorter time horizons, which inevitably means a less favourable ratio between these contributions and the liabilities they generate than is the case for the fund's accrued position. Special benefits for fishermen had a large impact on the deficit: The fund's actuary estimated that these special benefits comprised around $44 \%$ of the deficit by the end of 1995 (Bjarni Pórðarson, 1996, p. 4). Benefits to fishermen were lowered significantly via new bylaws that took effect in January 1997. The fund's actuary estimated that liabilities due to these special benefits were cut in half with the introduction of the new bylaws. However, these computations ignored any potential issues arising from the fishermen's possibility to draw on their pensions earlier than anticipated (Bjarni Pórðarson, 1997, p. 3). At this time, the fund seems to have achieved a balanced position between assets and total liabilities. Over the following two years, the fund's performance was deemed adequate in the absence of special benefits to fishermen (Bjarni Pórðarson, 1998, p. 5, 1999, p. 4). 
With the introduction of new bylaws on 1 October 1999, all fund members saw their benefit rights increased to similar levels enjoyed by fishermen so that everyone now enjoyed the same kind of rights. This action, of course, had an immediate and adverse impact on the fund's financial position as appraised by year-end 1999. In a later appraisal from year-end 2002, an additional set of assumptions were incorporated, for example, more recent statistics on mortality rates based on data from 1996-2000 as previous appraisals had used data from 1991-1995. This update of mortality rates had an adverse impact of $2.5 \%$ on the fund's liabilities (Bjarni Pórðarson, 2003, p. 2). This is a prime example of the importance of demographic assumptions when analyzing pension liabilities.

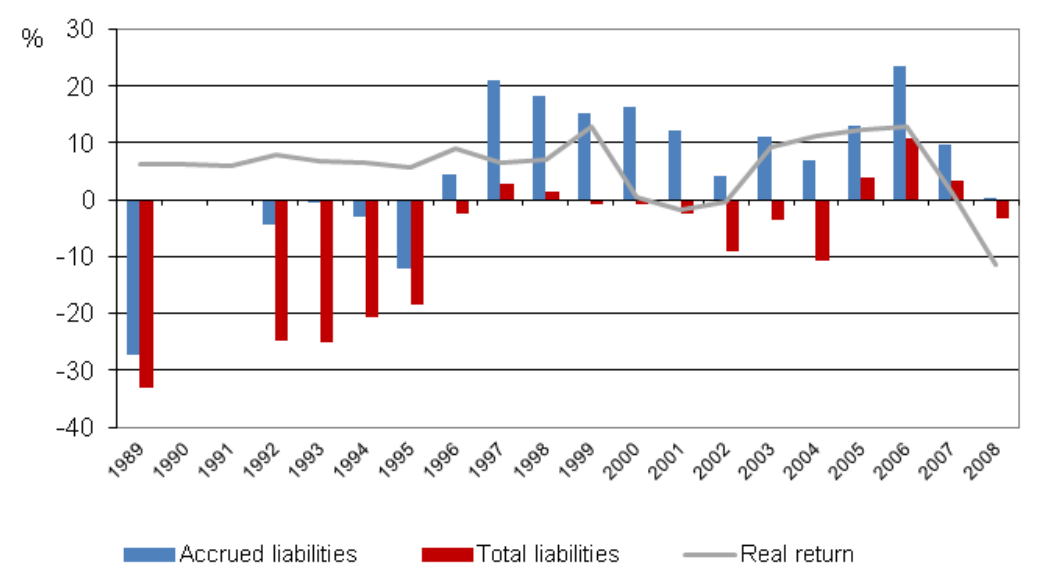

Sources: Actuarial appraisals of the Westman Islands Pension Fund.

Notes. Results are computed using a 3.5\% real discount rate, except for 1989 for which a 3\% rate in excess of changes in the wage index was employed. Annual returns are computed as $2 \mathrm{I} /(\mathrm{A}+\mathrm{B}-\mathrm{I})$, where I denotes income from the collection of interest payments, indexation and asset revaluation; A denotes total assets in the beginning of the year; and B total assets at year end.

Figure 2. Westman Islands Pension Fund: Actuarial assessments 1989-2008. Deficit or surplus in proportion to accrued and total liabilities

Demographic assumptions were further changed in the fund's appraisal for year-end 2004. Assumptions on mortality and survival probabilities were based on data from 1999-2003, whereas previous appraisals had employed data from 1996-2000. Additionally, the fund's assumptions on disability rates were revised by examining the experience of 17 other pension funds in the period 1998-2000. The results revealed large differences across funds, and that average disability frequencies were much higher than those assumed in the Danish actuarial appraisal standard G82 (d. beregningsgrundlaget G82), which had been used previously with a 30\% discount. Results further revealed that disability frequencies were significantly higher among members of the Westman Islands Pension Fund than among members of other funds that the study considered (Bjarni Pórðarson, 2005, p. 2). The disability rate among males was $82 \%$ higher for the Westman Islands Pension Fund compared to the average for other funds and similarly $24 \%$ higher for women (Bjarni Pórðarson, 2008, p. 2). In reaction to this pronounced discrepancy, the fund's appraisals would now assume disability rates for its members equal to the mean frequency of disability experienced by Icelandic fishermen, in addition to a $30 \%$ premium for active members. These updated assumptions on mortality and disability rates led to a severe deterioration of the fund's finances. Total liabilities exceeded assets by ISK 10.8 billion, obliging the fund's board to take action (Bjarni Pórðarson, 2005). Large changes were made to members' benefit rights via new rules introduced on 1 June 2005, 
although leaving accumulated benefits up until that date unchanged. Another action undertaken was to make pension rights accruals dependent on age. These changes, along with stellar returns on the fund's assets in 2005, led to a complete turnaround in the fund's finances: It was now running a surplus both in terms of accrued and total liabilities. Moreover, the difference between the accrued and total actuarial balance fell significantly in numerical terms. The fund's total position revealed that assets exceeded total liabilities by $4 \%$ (Bjarni Pórðarson, 2006).

As the above discussion makes clear, differing rates of disability frequency can have large impacts on a pension fund's position. In Iceland, such disability benefits have historically ranged from 6-43\% of total benefit payments (Pingskjal 335, 1990). In light of such pronounced differences across different funds it was deemed correct to level their positions. In 2006, a bill was passed that legally provided pension funds with claims to a special insurance fee, a measure designed to equalize funds' burdens arising from the payment of high disability benefits, as for the Westman Islands Pension Fund (Lög um breytingu á lögum nr. 113/1990, um tryggingagjald, með síðari breytingum nr. 177/2006).

The fund experienced further improvements in its financial position over the two subsequent years. By year-end 2006, its position had vastly improved thanks to robust investment returns. At that time, assets exceeded total liabilities by $10.8 \%$ which by the solvency rules adopted in the Pension Act of 1997 required the fund to increase member benefits. In the fund's actuarial appraisal for year-end 2006 it is stated that a $1 \%$ increase in benefits would reduce the ratio between assets and liabilities by $0.65 \%$. In light of these computations, benefits were increased by $10 \%$ in 2007. By the end of 2007, the fund's assets exceeded accrued liabilities by $9.8 \%$ and total liabilities by $3.2 \%$. As before, disability incidence was estimated using data from 1998-2002 with a 30\% premium. Clearly, the fund's position would have turned out weaker if the true disability incidence among its members had been used for appraisals. However, the fund's actuary considered the present value of the fund's contributions to the insurance fee scheme discussed above was high enough to offset this deficit. Overall the fund's position was thus assessed "rather good" at year-end 2007 (Bjarni Pórðarson, 2008, p. 3). In the fund's evaluation for year-end 2008, its actuary deemed it appropriate to use the same disability incidence but with a 50\% premium (Bjarni Pórðarson, 2009).

\subsection{The Engineers' Pension Fund}

Since the establishment of the Engineer's Pension Fund in 1954, its pension rights have been determined through a relationship dictating a specific ISK amount for each ISK of contributions (Bjarni Guðmundsson, 1996). Pension rights were non-indexed and rights accumulation determined by the equalization of annual accumulated rights of each member and the value of his or her annual contribution. Such computations were carried out using a $4 \%$ nominal rate of interest. Annual rights accumulation decreased with a member's age, as this implied a shorter period of investment returns. This arrangement was different to that of most other private labour market pension funds where the accumulation of rights did not depend on the age of the individual fund member. Upon the establishment in 1970 of the pension funds based on the points system described above, fund members above a certain age were granted additional rights beyond what their contributions could cover, the idea being that the next generation would ease the burden on members who were relatively young at the time, and so on. 
The Engineers' Pension Fund was initially supposed to be a fund in which membership was voluntary. Members would not accumulate rights beyond what their own contributions permitted, given a set of typical actuarial assumptions. This implies that there was no need to account for future contributions and the obligations they would create when the fund's assets and liabilities were evaluated; the fund's structure automatically ensured a balanced position.

Actuarial appraisals for the Engineers' Pension Fund exist at five year intervals over the period 1959-1979 (K. Guðmundur Guðmundsson, 1961, 1966, 1971, 1976, n.d.). Further appraisals were carried out after 1982. Appraisals have been carried out annually since 1990. The real value of pension rights fell sharply in the 1980s due to high inflation as assets were non-indexed. The fund's board reacted to this problem by providing members with supplementary payments, termed Christmas bonuses. The board finally decided in 1979 to provide insurance against inflation through additional benefit payments so that pensioners were ensured benefits amounting to $80 \%$ of contributions as determined by an index of living costs. This was a temporary solution implemented while the fund's bylaws were being revised.

The $80 \%$ rule described above was maintained until the fund's bylaws were amended in 1991. The fund's position was strong at that time and assets exceeded liabilities by a large amount, as pension rights were non-indexed. The amendments stipulated that rights would now be indexed using the credit terms index (Engineers' Pension Fund, n.d. art. 10). Actuarial appraisals would now be carried out every three years at least (Engineers' Pension Fund, n.d., art. 16.5). If the fund was running a surplus, its board would have to increase benefit rights according to the actuary's suggestions. However, the board was also allowed to allocate part or all of a surplus to a special reserve fund. If the appraisal revealed a deficit that would not be funded out of the special reserve fund, the board was obliged to lower benefits accordingly. Benefit rights that members had accumulated prior to the indexation of benefits would be recalculated according to the new benefit stipulations and indexed from that point on (Engineers' Pension Fund, n.d., art. 20.1). Furthermore, the decision was made to allocate some portion of the special fund reserves to increasing the pensions of members with the lowest rights according to the $80 \%$ rule.

Some of the new rules by the fund, along with the execution of these rules, were challenged before the courts. The fund would not allocate any of its potential surpluses to members who were very close to retirement, as they had already been guaranteed additional benefits in excess of accumulated contributions. As mentioned above, a special reserve fund had been established for this purpose. This differential treatment of fund members was deemed unlawful by the Supreme Court of Iceland (Supreme Court Decision of January 27, 2000 in case no. 57/1999; Supreme Court Decision of October 14, 1999 in case no. 58/1999; Supreme Court Decision of October 14, 1999 in case no. 59/1999). The court argued that stipulations in the fund's bylaws concerning these issues should apply to all fund members, as fund members were not only those who currently contributed to the fund, but also retirees and the disabled. However, the Supreme Court rejected requests for full indexation, thereby confirming a ruling by the Reykjavík District Court, which stated that benefit rights should be indexed according to the $80 \%$ rule introduced in 1979.

This ratio of indexation has changed over the years. After the fund's appraisal in 1995, the ratio was raised from $80 \%$ to $90 \%$. It was reduced again to $80 \%$ in mid-2000. Changes were made to the fund's rules in January 2001 - changes that are often referred to as the "sunset" stipulations of the $80 \%$ rule, as they effectively mark the end of the arrangement. An article which concerned additional benefit payments due to inflation was deleted. The practice of relating both the ratio and differences in rights to an estimate of members' rights at each time, 
as well as the special reserve fund, was abandoned. Instead, members' accumulated rights, without considering additional payments arising from the allocation of profits in 1991-2000, increased so that they would reach at least $80 \%$ of the rights that fully indexed contributions in 2000 granted. In 2007, this threshold was raised to $90 \%$.

Accumulated rights were lowered by 5\% in December 2005 in light of the fund's financial position. The cut did not last long as rights were again increased by $5.31 \%$ in 2006 after the annual evaluation revealed a surplus.

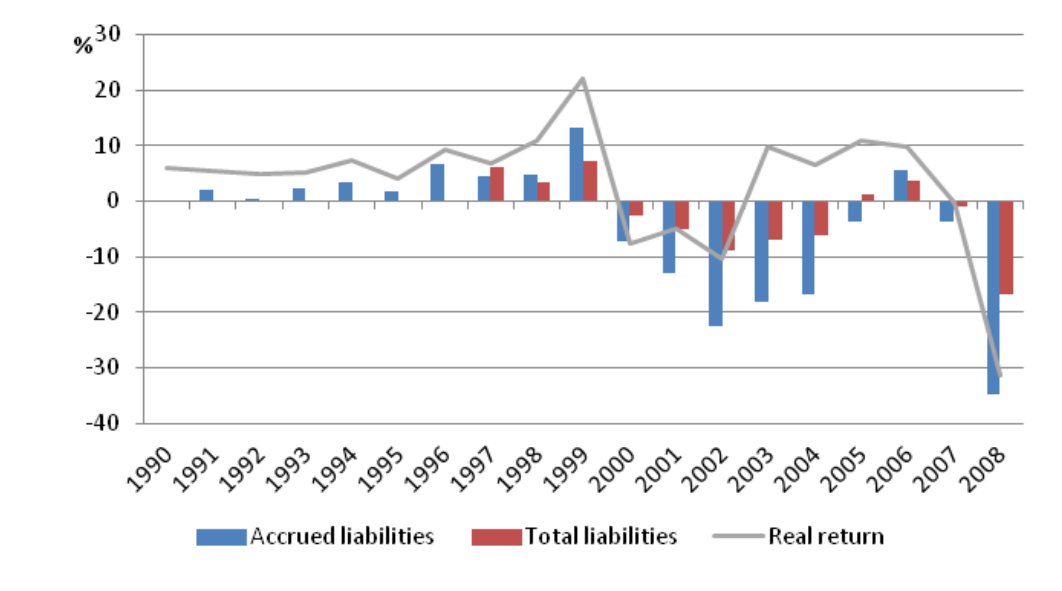

Sources: Actuarial appraisals of the fund.

Remarks. Results are computed based on a 3.5\% real discount rate. Returns each year are computed as 2I/(A+B-I) where I denotes income from the collection of interest, indexation and asset revaluation, A denotes assets at the beginning of the year, and $B$ assets at year end. ${ }^{13}$

Figure 3. The Engineers' Pension Fund: Actuarial assessments 1990-2008. Deficit or surplus in proportion to accrued and total liabilities

As described above, the accumulation of rights within the Engineer's Pension Fund is based on the principle that contributions be sufficient to cover rights. This is also true in most other funds, albeit to a lesser degree due to the fact that uniform accruals still apply for a part of members' contributions. The principle applied in the Engineer's Pension Fund explains why in Figure 3 the total position shows a lesser deficit than the accrued position in case the latter is in deficit. Thus, there is no redistribution of pension benefits across members other than that achieved through the fund's typical collective insurance role. An improvement in the fund's financial position up until the new millennium may primarily be traced to strong asset returns, where indexation played an important role, and greater choices regarding investment opportunities.

In the following years, the fund's position deteriorated mostly because of poor investment returns, but also because of higher life expectancies, a development which has increased the fund's liabilities considerably. Finally, provisions in the fund's rules, stipulating that any surplus should be allocated to the increase of benefit rights, imply that the fund accumulates no reserves and therefore experiences instant deficits in times of adversity. In recent years, deficits have been met by proportional cuts in pension rights.

${ }^{13}$ Results are obtained by dividing interest income with average asset position over the year and subtracting half of annual interest income; this is an approximation of the fund's mid-year position. 


\subsection{The Physicians' Pension Fund}

The Physicians' Pension Fund was founded in 1966 and ceased its general operations in 2006 when it became a part of the Almenni Pension Fund. An actuarial assessment of the fund from 1993 reveals that it was close to being in a balanced position (Guðjón Hansen, 1994). The fund's assets and the present value of future contributions, in proportion to total liabilities, was $76 \%$ in 1982. This ratio increased to $89.4 \%$ in 1989 and further to $97.6 \%$ in 1993 . These results were computed using an annual discount rate of 3\%. The fund's weak financial position in 1982 can be traced to the fact that, from inception, investment returns had been very low compared to wage increases. The fund saw its performance fluctuate wildly in 1983-1987, but over the years 1988-1993 it was consistently very good (Guðjón Hansen, 1994, p. 7).

At year-end 1989 over $94 \%$ of the fund's total assets were held in bonds. This ratio fell to approximately $90 \%$ at year-end 1993 . By that time, 3.6\% of the fund's assets were allocated to equities (Guðjón Hansen, 1994, p. 4). An actuarial appraisal from 1993 shows that the fund held large amounts of high-yield bonds, as did most other funds at the time. If this had been fully incorporated into the appraisal, instead of discounting by a 3\% rate of interest on all assets, the fund's position would have shown a stronger result, with assets higher than indicated by the balance sheet and thus a more favourable ratio of assets to liabilities. The fund's actuary at the time stated that "...the trend towards a much stronger financial position, as revealed by the fund's appraisal in 1989, has continued over the past four years, and I now believe that the fund is sufficiently strong to meet its total and accrued liabilities." (Guðjón Hansen, 1994, p. 8)

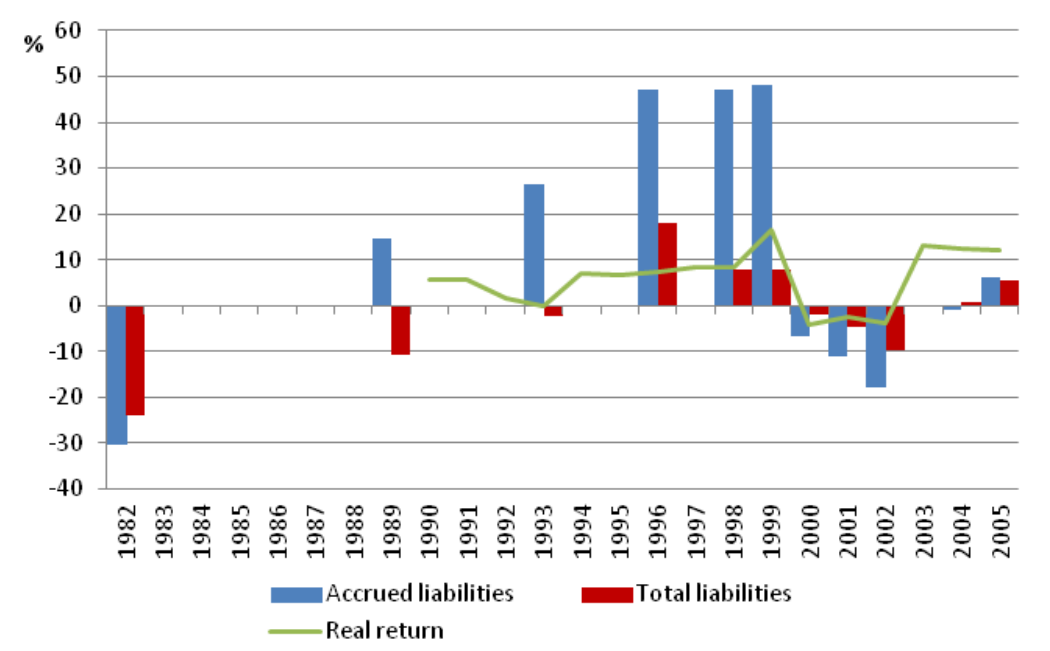

Sources: Actuarial appraisals of the fund.

Remarks. Results for 1982, 1989 and 1993 are computed using a 3\% real discount rate of interest beyond increases in the wage index; results for all other years assume a 3.5\% real interest rate. Returns each year are computed as $2 \mathrm{I} /(\mathrm{A}+\mathrm{B}-\mathrm{I})$ where I denotes income from the collection of interest, indexation and asset revaluation, A denotes assets at the beginning of the year, and $B$ assets at year end.

Figure 4. The Physicians' Pension Fund: Actuarial assessments 1982-2005. Deficit or surplus as a proportion of accrued and total liabilities

From October 1995, base salaries, which are used as a reference in the determination of pension benefits, were adjusted according to changes in the consumer price index. New bylaws for the fund were introduced in 1996. An actuarial appraisal of the fund at year-end 1996 shows that its position had greatly improved since the last appraisal dated from 1993. This improvement was the result of changes in the determination of pension rights, as discussed above, and the fact that appraisals now assumed a 3.5\% real rate of interest instead 
of $3 \%$ as had been applied previously. Additionally, the fund had experienced attractive investment returns over the preceding few years. It was thus concluded that the fund's strong position permitted a $10 \%$ increase in benefits according to rights accumulated by year-end 1996 (Bjarni Guðmundsson, 1997).

The fund confirmed new rules in April 2000. A fundamental change concerned the accumulation of pension rights which would now depend on a member's age. Members' rights were also revised in April 2000 but they were not set lower than stipulated by older rules. Pension rights were ultimately increased by $45 \%$ through these changes (Bjarni Guðmundsson, 2001). The changes made to pension rights accumulation resulted in the disappearance of the fund's deficit with respect to future obligations. After pension rights were increased in 2000, as discussed above, the fund's total position was approximately balanced. However, in the three years that followed, the fund suffered rather poor investment returns. In January 2003, the board thus had to lower rights on all contributions provided up until year-end 2002. This cut in benefits led the fund to achieve a balance between assets and liabilities and by year-end 2006 its actuarial position was quite strong (Bjarni Guðmundsson, 2006).

\subsection{Summary of the financial evolution of the four funds}

The investigation of the four pension funds presented in this section highlights their different operating conditions. The great impact of disability incidence on the financial position of the Westman Islands Pension Fund is particularly noticeable. All four funds reached a balanced position around the same time, except for the Pension Fund of Commerce, which achieved that state slightly earlier. At year-end 1991 the Pension Fund of Commerce already had sufficient assets to cover its liabilities on an actuarial basis. The other funds appear to have reached similar levels of financial strength around 1996-1997, as is exhibited in Figure 5, although it is difficult to state with great precision as actuarial appraisals were not carried out annually before this period.

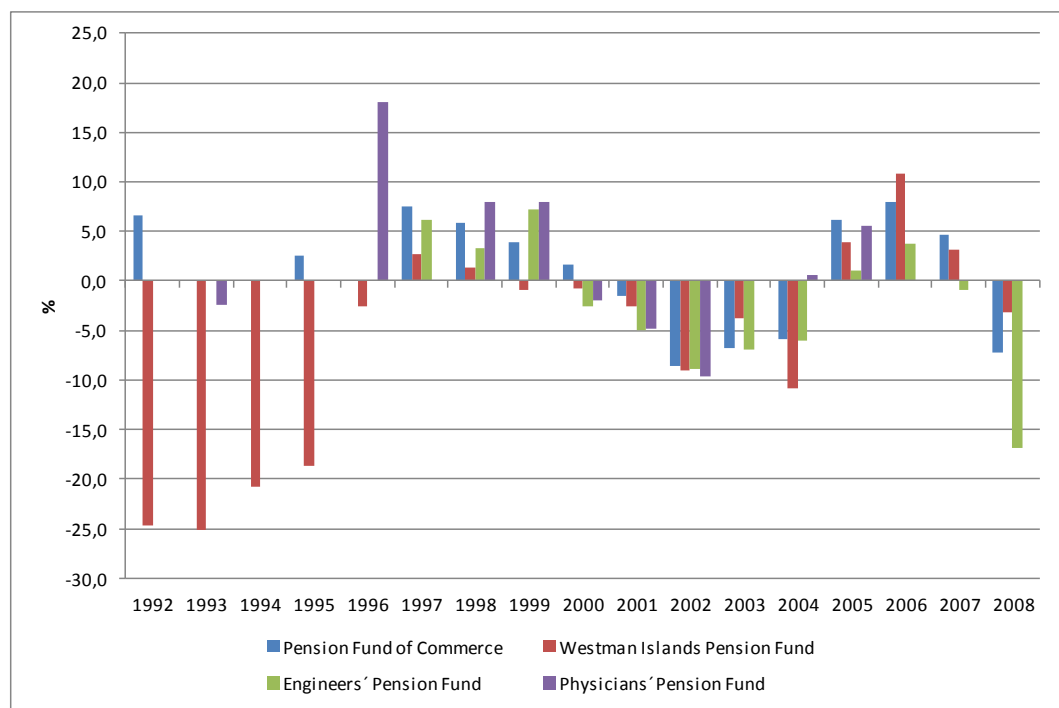

Remarks. Results are based on a real discount rate of 3.5\% except in the following instances: For the Pension Fund of Commerce in 1992, where a real discount rate of 3\% was used, and for the Physicians' Pension Fund in 1993, where a real discount rate of $3 \%$ was used.

Figure 5. Four funds: Results from actuarial assessments 1992-2008. Deficit or surplus as a proportion of total liabilities 
The overview of the four funds presented in this section has highlighted the different factors that affected their financial performance. The factors that contributed towards the funds' financial turnaround will be explored in greater depth below.

\section{Overview of the financial performance of principal funds}

It is enlightening to explore the performance of major private labour market pension funds and compare their general developments to the overview of the four funds presented in the previous section. The analysis presented in this section will explore the following pension funds: the Pension Fund of Commerce, the Dagsbrún and Framsókn Pension Fund, the Cooperative Pension Fund, the Eastern Iceland Pension Fund, the Westfjords Pension Fund, and the Westman Islands Pension Fund. These funds were in part selected for their size, as their total assets comprised over half of all assets held by the private labour market funds over the period explored, up to year-end 2003. Additionally, greater and more reliable data for these funds exist for the period under investigation than for other private labour market funds.

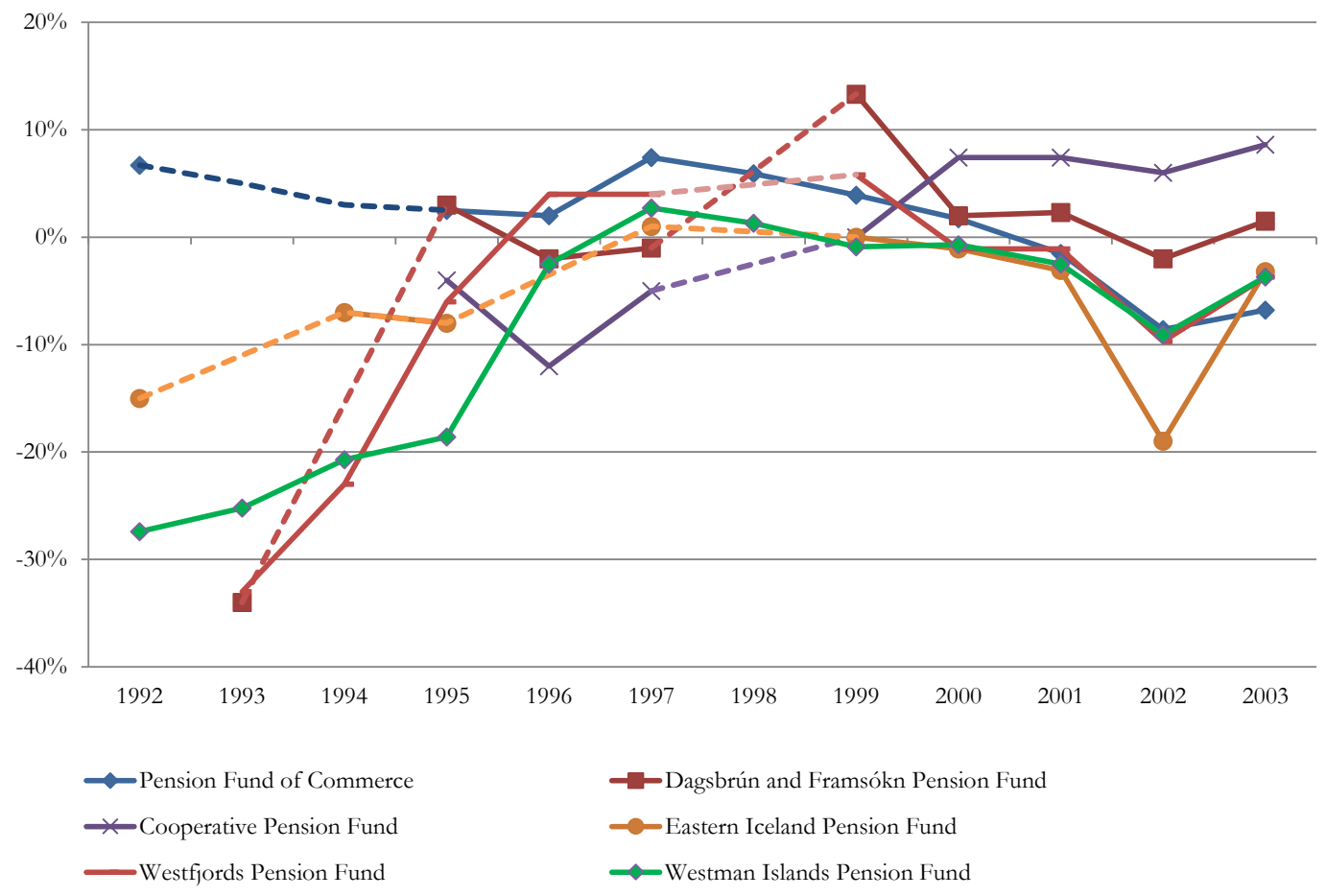

Source: Central Bank of Iceland and funds' annual reports.

Note. Position determined by applying a 3.5\% discount rate.

Figure 6. Actuarial position of major private labour market pension funds 1992-2003

Figure 6 shows that most funds achieved a balance between assets and liabilities around 1994-1996, and it is interesting how most of them reached such a state within such a short time frame. In this period, all funds primarily directed their investments towards indexed asset classes and also began indexing benefits to the consumer price index instead of wages. At this time, equities still comprised a very low fraction of the funds' portfolios and the amount of foreign assets held was negligible. 


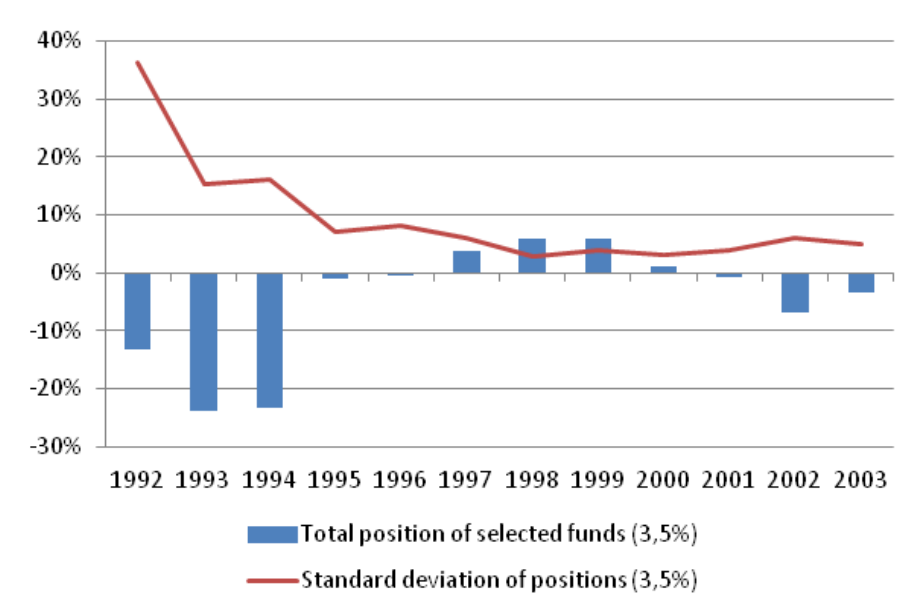

Source: Central Bank of Iceland and actuarial assessments of funds.

Remark. Breaks in the data are due to the fact that actuarial appraisals of funds are not available for every year, in particular the early years.

Figure 7. Weighted average actuarial position of funds and standard deviation 1992-2003

The turnaround in the financial position of these funds reveals a broader, systemic development. Figure 7 highlights this phenomenon. It shows the weighted average of the total position of 12 private labour market pension funds over the years 1992-2003. ${ }^{14}$ The standard deviation between the positions of individual funds is also provided. The figure underlines the correlation between funds in two ways; the funds' weighted total actuarial position reached a more balanced position over the time interval, and the standard deviation between funds fell sharply, as expected. Thus, there is a quite remarkable convergence process that emerges when the pension system is viewed as a whole over the period considered. This convergence process is clearly evident by the sharply falling standard deviation of the actuarial assessments of the individual funds in the system, as well as the convergence towards a balance between pension assets and liabilities shown in the average actuarial position of the funds. This development could be described as a systemic turnaround of private labour market funds in the sense that they seem to have reached an actuarially balanced position around the same time, where an actuarially balanced position indicates that the funds generally hold sufficient assets to cover their liabilities. This period was further marked by similar operational changes across the funds through wider collaboration between the social partners, the Icelandic Pension Fund Association and the introduction in 1997of the new Pensions Act.

14 The funds are the Pension Fund of Commerce, the Dagsbrún and Framsókn Pension Fund, the Co-operation Pension Fund, the Almenni Pension Fund, the Eastern Iceland Pension Fund, the West Fjords Pension Fund, the Sudurnes Pension Fund, the Westman Islands Pension Fund, the Sókn Pension Fund, the Physicians' Pension Fund, the Engineers' Pension Fund and the Western Iceland Pension Fund. 


\section{Conclusion}

The bulk of the pension funds in the private labour market reached a balanced position in the mid-1990s. The convergence found in financial positions across funds is of particular interest, as the funds studied achieved an actuarially balanced position around the same time. These conclusions are consistent with the analysis of the four funds analyzed in the paper. ${ }^{15}$

The overriding common factor across the funds behind this result is a strong return on assets. Inflation indexed bonds comprised the majority share of funds' asset portfolios at the time, which implies that the turnaround can largely be traced to indexation and solid returns on domestic bonds. This is not surprising given that the issuer of an indexed bond assumes all the risk linked to price developments over the lifetime of the bond. At this time pension funds mostly held domestic indexed bonds in their portfolios. Portfolio allocations to equities were not significant as the Icelandic stock market was still quite underdeveloped. ${ }^{16}$ At the time foreign currency denominated assets had not entered into pension fund portfolios. ${ }^{17}$ This implies that favourable returns on domestic bonds were the primary source of the overall positive investment returns in the period. The return on domestic bonds can be separated into two effects: inflation indexation and strongly positive real returns. By the introduction of general price indexation of bonds the risk associated with price inflation was effectively removed from new bonds acquired by the pension funds. Additionally, in the preceding period where liabilities were linked to a wage scale this was effected by a 5-year averaging delay causing a significant reduction in the real value of benefits.

Other decisions made by the funds significantly contributed to the turnaround. In this respect a reduction in benefits plays an important role, particularly the reductions in spousal pension rights, which were changed from permanent rights to temporary rights. It can be seen in the case of the Westman Islands Pension Fund that the fund's total cost due to changes in spousal pension rights, in excess of what IPFA bylaws strictly stipulated, amounted to around $2 \%$ of the fund's total liabilities. Another decision that deserves mention is that of replacing the wage index by a price index in determining benefits. In view of the generally accepted observation that over time wage increases exceed price increases due to productivity increases, wage indexation of pension benefits can be viewed as more costly for pension funds than price indexation. In this sense the switch from a wage reference to a price reference amounts to a cut in benefits. This measure was implemented concomitantly with an increase in the discount rate from 3.0 to $3.5 \%$ which on its own, as shown by two independent approaches in Ólafur Ísleifsson $(2009,2012)$, immediately improves the actuarial balance of the pension funds by an order of $10 \%$ of total liabilities. ${ }^{1819}$

It may be suggested that the radical change in yields on pension funds bond holdings effected by the introduction of a general price indexation of bonds, together with relatively high nominal interest rates, amount to a structural break in their operating conditions and is instrumental in the turnaround of their actuarial balances. Such effects of a structural break

${ }^{15}$ See also Tryggvi Pór Herbertsson (2004).

${ }^{16}$ Sigurður E. Guðmundsson (2005) discusses the funds' legal obligations regarding purchases of government-guaranteed bonds.

${ }^{17}$ For a more detailed discussion of investment strategies of the funds, see Ólafur Ísleifsson (2007).

${ }^{18}$ On the choice of the discount rate see Ólafur Ísleifsson (2007, p. 162), and Ólafur Ísleifsson (2013a, Chapter 3, Section 2.2).

${ }^{19}$ For an analysis of the effect of increased longevity on pension fund finances see Ólafur Ísleifsson (2012, pp. 551-552), and Ólafur Ísleifsson (2013a, Chapter 5, Section 2.3). 
might possibly be made the subject of statistical testing, perhaps on a panel-data basis. An approach of this kind, however, would require careful statistical modeling and lies beyond the confines of this paper.

\section{References}

Ársskýslur fjármálaeftirlitsins. (various years). [Annual reports of the Icelandic Financial Supervisory Authority].

Bjarni Guðmundsson. (1990, May 15). Til stjórnar Lífeyrissjóðs Verkfræðingalfélags] Íslands. Án titils. [Helstu niðurstöður úr tryggingafræðilegri úttekt miðað við árslok 1988]. Unpublished.

Bjarni Guðmundsson. (1991, May 17). Til stjórnar Liffeyrissjóðs Verkfræðingafélags Íslands. Án titils. [Helstu niðurstöður úr tryggingafræðilegri úttekt miðað við 31.12. 1990]. Unpublished.

Bjarni Guðmundsson. (1992, May 25). Til stjórnar Lífeyrissjóðs Verkfræððngafélags Íslands. Án titils. [Helstu niðurstöður úr tryggingafræðilegri úttekt miðað við 31.12. 1991]. Unpublished.

Bjarni Guðmundsson. (1993, May 17). Til stjórnar Lífeyrissjóðs Verkfræððngafélags Íslands. Án titils. [Helstu niðurstöður úr tryggingafræðilegri úttekt miðað við 31.12. 1992]. Unpublished.

Bjarni Guðmundsson. (1994, May 23). Til stjórnar Lífeyrissjóðs Verkfræððingafélags Íslands. Án titils. [Helstu niðurstöður úr tryggingafræðilegri úttekt miðað við 31.12. 1993]. Unpublished.

Bjarni Guðmundsson. (1995, May 20). Til stjórnar Lífeyrissjóðs Verkfræðingafélags Íslands. Án titils. [Helstu niðurstöður úr tryggingafræðilegri úttekt miðað við 31.12. 1994]. Unpublished.

Bjarni Guðmundsson. (1996). Breyting reglugerðar LVFÍ árið 1990. Unpublished.

Bjarni Guðmundsson. (1996, May 11). Til stjórnar Lífeyrissjóðs Verkfræðingafélags Íslands. Án titils. [Helstu niðurstöður úr tryggingafræðilegri úttekt miðað við 31.12. 1995]. Unpublished.

Bjarni Guðmundsson. (1997). Tryggingafræð̇leg úttekt. Liffeyrissjóður lækna 31. 12. 1998. Unpublished.

Bjarni Guðmundsson. (1997, May 19). Til stjórnar Lífeyrissjóðs Verkfræððingafélags Íslands. Án titils. [Helstu niðurstöður úr tryggingafræðilegri úttekt miðað við 31.12. 1996]. Unpublished.

Bjarni Guðmundsson. (1997, November 22). Tryggingafræðileg úttekt. Lífeyrissjóður lækna 31. 12. 1996. Unpublished.

Bjarni Guðmundsson. (1998, May 13). Til stjórnar Lífeyrissjóðs Verkfræðingafélags Íslands. Án titils. [Helstu niðurstöður úr tryggingafræðilegri úttekt miðað við 31.12. 1997]. Unpublished.

Bjarni Guðmundsson. (1999, May 20). Skýrsla um tryggingafræðilega úttekt á Líf. Verk 1998. Unpublished.

Bjarni Guðmundsson. (2000, April 12). Tryggingafræðileg úttekt. Lífeyrissjóður lækna 31. 12. 1999. Unpublished.

Bjarni Guðmundsson. (2000, May 15). Til stjórnar Lífeyrissjóðs Verkfræðingafélags Íslands. Án titils. [Helstu niðurstöður úr tryggingafræðilegri úttekt miðað við 31.12. 1999]. Unpublished. 
Bjarni Guðmundsson. (2001). Tryggingafræðileg úttekt. Lífeyrissjóður lækna 31. 12. 2000. Unpublished.

Bjarni Guðmundsson. (2001, May 16). Tryggingafræðileg úttekt. Lífeyrissjóður verkfræðinga 31. 12. 2000. Unpublished.

Bjarni Guðmundsson. (2002, March 5). Tryggingafræðileg úttekt. Lífeyrissjóður lækna 31. 12. 2001. Unpublished.

Bjarni Guðmundsson. (2002, May 11). Tryggingafræðileg úttekt. Lífeyrissjóður verkfræðinga 31. 12. 2001. Unpublished.

Bjarni Guðmundsson. (2003, March 6). Tryggingafræðileg úttekt. Lífeyrissjóður lækna 31. 12. 2002. Unpublished.

Bjarni Guðmundsson. (2003, May 13). Tryggingafræðileg úttekt. Lífeyrissjóður verkfræðinga 31. 12. 2002. Unpublished.

Bjarni Guðmundsson. (2004, April 14). Tryggingafræðileg úttekt. Lifeyrissjóður verkfræðinga 31. 12. 2003. Unpublished.

Bjarni Guðmundsson. (2005, April 20). Tryggingafræðileg úttekt. Liffeyrissjóður verkfræðinga 31. 12. 2004. Unpublished.

Bjarni Guðmundsson. (2005, March 17). Tryggingafræðileg úttekt. Lífeyrissjóður lækna 31. 12. 2004. Unpublished.

Bjarni Guðmundsson. (2006). Tryggingafræðileg úttekt. Lífeyrissjóður lækna 31. 12. 2005. Unpublished.

Bjarni Guðmundsson. (2006, March 27). Tryggingafræðileg úttekt. Liffeyrissjóður verkfræðinga 31. 12. 2005. Unpublished.

Bjarni Guðmundsson. (2007, March 12). Tryggingafræðileg úttekt. Lífeyrissjóður verkfræðinga 31. 12. 2006. Unpublished.

Bjarni Guðmundsson. (2008, March 31). Tryggingafræð̇leg úttekt. Liffeyrissjóður verkfræðinga 31. 12. 2007. Unpublished.

Bjarni Pórðarson. (1983). Varðandi athugun á fjárhagsstöðu Lifeyrissjóðs verzlunarmanna pr. 31. 12. 1982. Hafnarfjörður: Unpublished.

Bjarni Pórðarson. (1996). Athugun á fjárhagsstöðu Lífeyrissjóðs Vestmannaeyja í árslok 1995. Hafnarfjörður: Unpublished.

Bjarni Pórðarson. (1997). Athugun á fjárhagsstöðu Lifeyrissjóðs Vestmannaeyja í árslok 1996. Hafnarfjörður: Unpublished.

Bjarni Pórðarson. (1998). Athugun á fjárhagsstöðu Lífeyrissjóðs Vestmannaeyja í árslok 1997. Hafnarfjörður: Unpublished.

Bjarni Pórðarson. (1999). Athugun á fjárhagsstöðu Lífeyrissjóðs Vestmannaeyja í árslok 1998. Hafnarfjörður: Unpublished.

Bjarni Pórðarson. (2000, March 28). Athugun á fjárhagsstöðu Lífeyrissjóðs Vestmannaeyja í árslok 1999. Hafnarfjörður: Unpublished.

Bjarni Pórðarson. (2001, April 17). Athugun á fjárhagsstöðu Lífeyrissjóðs Vestmannaeyja í árslok 2000. Hafnarfjörður: Unpublished.

Bjarni Pórðarson. (2002, March 22). Athugun á fjárhagsstöðu Lífeyrissjóðs Vestmannaeyja í árslok 2001. Hafnarfjörður: Unpublished.

Bjarni Pórðarson. (2003). Athugun á fjárhagsstöðu Lífeyrissjóðs Vestmannaeyja í árslok 2002. Hafnarfjörður: Unpublished.

Bjarni Pórðarson. (2004, March 16). Athugun á fjárhagsstöðu Lífeyrissjóðs Vestmannaeyja í árslok 2003. Hafnarfjörður: Unpublished. 
Bjarni Pórðarson. (2005). Athugun á fjárhagsstöðu Lífeyrissjóðs Vestmannaeyja í árslok 2004. Hafnarfjörður: Unpublished.

Bjarni Pórðarson. (2006). Athugun á fjárhagsstöðu Lífeyrissjóðs Vestmannaeyja í árslok 2005. Hafnarfjörður: Unpublished.

Bjarni Pórðarson. (2008). Athugun á fjárhagsstöðu Lífeyrissjóðs Vestmannaeyja í árslok 2007. Hafnarfjörður: Unpublished.

Bjarni Pórðarson. (2009). Lífeyrissjóður Vestmannaeyja. Tryggingafræðilegt uppgjör pr. 31.12.08. Fylgiskjöl 3 og 3(B). Unpublished.

Engineers' Pension Fund. (n.d.). Sampykktir Liffeyrissjóðs verkfræðinga [Rules].

Fjármálaeftirlitið. (various years). Lífeyrissjóðir. Ársreikningar ásamt kennitölum og öðrum upplýsingum. [FME Pension funds: Annual accounts and other information]. Retrieved from http://www.fme.is/utgefid-efni/tolulegar-upplysingar/.

Guðjón Hansen. (1985). Tryggingafræðilegt uppgjör SAL-sjóða. Erindi á aðalfundi Sambands almennra lífeyrissjóða, 18. nóvember 1985. [Actuarial appraisal of APF funds, presentation given at an APF annual meeting, November 18, 1985]. Unpublished.

Guðjón Hansen. (1990). Athugun á stöðu Lífeyrissjóðs Vestmannaeyinga í árslok 1989. Reykjavík: Unpublished.

Guðjón Hansen. (1993). Um afkomu Lífeyrissjóðs Vestmannaeyinga árin 1990-1992 og fjárhagsstöðu i árslok 1992. Reykjavík: Unpublished.

Guðjón Hansen. (1994). Fjárhagsleg áhrifbreyttra ákvæða um makalífeyri. Reykjavík: Unpublished.

Guðjón Hansen. (1994, April 5). Um afkomu og fjárhagsstöðu Lífeyrissjóðs Vestmannaeyinga árið 1993. Reykjavík: Unpublished.

Guðjón Hansen. (1994, November 11). Athugun á stöðu Lífeyrissjóðs lækna í árslok 1993. Unpublished.

Guðjón Hansen. (1995). Athugun á stöðu Lífeyrissjóðs Vestmannaeyinga í árslok 1994. Reykjavík: Unpublished.

Hallgrímur Snorrason. (1988). Vandamál lífeyrissjóðanna vegna liðins tíma. Presented at a conference for Landssamband lífeyrissjóða and Samband almennra lífeyrissjóða. Unpublished.

Jakob F. Ásgeirsson. (1986). Lífeyrissjóđur verzlunarmanna 1956-1986. Unpublished.

Jóhannes Nordal. (1975). Erindi á fundi Sambands almennra lífeyrissjóða. Unpublished.

K. Guðmundur Guðmundsson. (1961). Skýrzla um athugun á fjárhag Lífeyrissjóðs V. F. Í. pr. 31. des. 1959. Reykjavík: Unpublished.

K. Guðmundur Guðmundsson. (1966). Athugun á fjárhag Lifeyrissjóðs V. F. Í. pann 31. des. 1964. Reykjavík: Unpublished.

K. Guðmundur Guðmundsson. (1971). Athugun á fjárhag Lifeyrissjóðs V. F. Í. pann 31. des. 1969. Reykjavík: Unpublished.

K. Guðmundur Guðmundsson. (1976). Athugun á fjárhag Liffeyrissjóðs V. F. Í. pann 31.des. 1974. Reykjavík: Unpublished.

K. Guðmundur Guðmundsson. (n.d.). Athugun á fjárhag Lífeyrissjóðs V. F. Í. pann 31. des. 1979. Reykjavík: Unpublished.

K. Guðmundur Guðmundsson. (n.d.). Lífeyrissjóður V. F. Í. Athugun á fjárhag pr. 31. des. 1982. Reykjavík: Unpublished.

Landssamtök lífeyrissjóða [Icelandic Pension Fund Association]. [2009]. Operations report 2008 2009. Reykjavík: Unpublished.

Lög um breytingu á lögum nr. 113/1990, um tryggingagjald, með sídari breytingum nr. 177/2006.

Lög um stjórn efnahagsmála o.fl. nr. 13/1979. 
Ólafur Ísleifsson. (2007). Skipan lífeyrismála á almennum vinnumarkaði. Stjórnmál og stjórnsýsla, 3(2), 141-178.

Ólafur Ísleifsson. (2009). Sviptingar í fjárhag lífeyrissjóðanna. Stjórnmál og stjórnsýsla, 5(1), 123158.

Ólafur Ísleifsson. (2012). Vulnerability of pension fund balances. Stjórnmál og stjórnsýsla, 8(2), 543-564.

Ólafur Ísleifsson. (2013a). The Icelandic Pension System (Unpublished doctoral dissertation). University of Iceland, Reykjavík.

Ólafur Ísleifsson. (2013b). Pension benefits outside of the pension system. Stjórnmál og stjórnsýsla, 9(2), 473-488.

Pension Fund of Commerce. (1979). Ársskýrsla fyrir árið 1978. Reykjavík: Author.

Pension Fund of Commerce. (1980). Sampykktir Lífeyrissjóðs verzlunarmanna [Rules, Pension Fund of Commerce]. In Ársskýrsla fyrir árið 1979. Reykjavík: Author.

Pension Fund of Commerce. (1981). Ársskýrsla fyrir árið 1980. Reykjavík: Author.

Pension Fund of Commerce. (1991). Ársskýrsla fyrir árið 1990. Reykjavík: Author.

Pension Fund of Commerce. (1992). Ársskýrsla fyrir árið 1991. Reykjavík: Author.

Pension Fund of Commerce. (1994). Ársskýrsla fyrir árið 1993. Reykjavík: Author.

Pension Fund of Commerce. (1995). Ársskýrsla fyrir árið 1994. Reykjavík: Author.

Pension Fund of Commerce. (2006). Ársskýrsla fyrir árið 2005. Reykjavík: Author.

Pétur H. Blöndal. (1976). Skýrsla. Útreikningur á fjárhag Lífeyrissjóðs verzlunarmanna pann 31. 12. 1975. Reykjavík.

Pétur H. Blöndal. (1986, April 9). Skýrsla. Útreikningur á fjárhagsstöðu Lífeyrissjóðs Verkfræðingafélags Íslands pann 31. des. 1983. Reykjavík: Unpublished.

Pétur H. Blöndal. (1986, April 9). Skýrsla. Útreikningur á fjárhagstjóni Lífeyrissjóðs Verkfræðingafélags Íslands vegna óverðtryggðra útlána miðað við 31. des. 1983 [Calculations of losses incurred by the Engineers' Pension Fund due to non-indexed lending]. Reykjavík: Unpublished.

Pétur H. Blöndal. (1988). Skýrsla (merkt sem drög). Útreikningur á fjárhag Lífeyrissjóðs verzlunarmanna pann 31. desember 1987. Reykjavík: Unpublished.

Pétur H. Blöndal. (1989, February 9). Viðbótarskýrsla við útreikningur (svo) á fjárhag Lífeyrissjóðs verzlunarmanna pann 31. desember 1987. Reykjavík: Unpublished.

Reglugerðir og sampykktir fyrir Lífeyrissjóð Vestmannaeyja. (n.d.) [Rules and bylaws, Westman Islands Pension Fund].

Sampykktir Gildis lífeyrissjóðs. (n.d.). [Rules, Gildi pension fund].

Sampykktir Landssamtaka lífeyrissjóða (n.d.). [Association of Pension Fund rules]. Retrieved from http://11.is/?page_id=5993

Seðlabanki Íslands. Bankaeftirlit. (1992-1998). Lífeyrissjóðir. Ársreikningar 1991 - 97. Reykjavík. [Central Bank of Iceland, Pension Funds: Annual accounts 1991-97].

Sigurður E. Guðmundsson. (2005). Lífeyrissjóðir 1960-1980. Tímamót í velferðarmálum eldra fólks (Unpublished master's thesis). University of Iceland, Reykjavík.

Skýrsla forseta um störf Alpýdusambands Íslands. (various years). [Icelandic Confederation of Labour, President's report].

Supreme Court Decision of January 27, 2000 in case no. 57/1999. Lífeyrissjóður verkfræðinga v. Birgir G. Frímansson.

Supreme Court Decision of October 14, 1999 in case no. 58/1999. Lífeyrissjóður verkfræðinga v. Gunnar K. Björnsson. 
Supreme Court Decision of October 14, 1999 in case no. 59/1999. Lífeyrissjóður verkfræðinga v. Ragnar S. Halldórsson.

Tryggvi Pór Herbertsson. (2004). Áhrif afnáms verðtryggingar á islensku lífeyrissjóðina. Greinargerð til Landssamtaka lífeyrissjóða. Unpublished.

Pingskjal 294. (1997-1998). Frumvarp til laga um skyldutryggingu lífeyrisréttinda og starfsemi lífeyrissjóða [Proposal for the Act on Mandatory Pension Insurance and the Operation of Pension Funds]. Alpingistídindi A-deild, 122. Retrieved from http://www.althingi.is/altext/122/s/0294.html

Pingskjal 335. (1990). Frumvarp til laga um tryggingagjald. Alpingistídindi A-deild, 113. Retrieved from http://www.althingi.is/altext/113/s/0335.html

Pórir Bergsson. (1972). Niðurstöður útreiknings á fjárhag Lifeyrissjóðs verzlunarmanna 31. desember 1970 mеð greinargerð. Reykjavík: Unpublished. 